\title{
Who Are Their Leaders? College Students Perceptions of and Engagement with Campus Leaders and Administrators
}

\author{
Stephanie Rizzo ${ }^{1}$, Dana J. Tribble ${ }^{2} \&$ Louis S. Nadelson ${ }^{1}$ \\ ${ }^{1}$ College of Education, University of Central Arkansas, Conway AR, USA \\ ${ }^{2}$ College of Education, Arkansas Tech University, Russellville, AR, USA \\ Correspondence: Louis Nadelson, College of Education, University of Central Arkansas, Conway AR, 72035, \\ USA. Tel: 501-450-3254. E-mail: LNADELSON1@uca.edu
}

\author{
Received: May 1, $2021 \quad$ Accepted: June 8, $2021 \quad$ Online Published: June 16, 2021 \\ doi:10.5539/hes.v11n3p43 URL: https://doi.org/10.5539/hes.v11n3p43
}

\begin{abstract}
College students' interactions with campus leaders is critical to their success, particularly in situations of distress. Yet, little is known about college students' knowledge, perceptions, and identification of campus administrators, faculty members, and staff as leaders and their interactions with these campus leaders. To fill the gap in the literature, we applied a cross-sectional methodology to gather a combination of quantitative and qualitative data using an online survey. We had 60 first-year students participate in our exploratory research by fully completing our survey. We found that students identified their advisors as leaders on campus. We also found most of our participants avoided campus administrators in fear of judgment, intimidation, and feelings of anxiety. Our results have implications for campus leadership, college administrators, student retention, and campus climate. Following our results, we discuss implications for practice and offer additional recommendations for future research.
\end{abstract}

Keywords: leadership, leaders, students' engagement with leaders, students' perceptions of leaders, identifying leaders, first-year students, student retention, campus climate

\section{Introduction}

Leadership plays a critical role in college student success (Kuh et al., 2005). Campus leadership influences the climate of the campus, the offered programs, the selection and retention of faculty members, and supports for student learning (Bolman \& Gallos, 2010; Love, Trammell, \& Carter, 2009). While campus leaders fulfill many essential roles, they tend to be removed from and distal from students. Thus, many undergraduate students are likely to have little knowledge of the different leadership roles on campus and may not even know who is filling the most conspicuous positions, such as the institutional president.

A lack of student awareness of who the leaders are on campus may have ramifications for student retention. If students do not know who the campus leaders are, they may be limited in their ability to gain support in times of need, and they also may fail to develop a sense of belonging at the institution. Given the potential ramifications of students' knowledge of who campus leaders are, it is essential to document their levels of understanding of campus leaders. Further, it is necessary to establish who the students contact on their campus for support when they are in situations of need or academic crisis. In our search of the literature, we were unable to locate any studies that report on college students' perceptions and knowledge of campus leadership and who on campus they go to for help in times of academic need or distress. Thus, the purpose of our research was to address the gap in the literature by empirically documenting college students' perceptions and knowledge of campus leadership. Specifically, we conducted our research to answer the question: What are college students' knowledge, perceptions, and interactions with campus leaders?

\section{Literature Review}

\subsection{College Students Perceptions of Leaders and Leadership}

Astin and Astin (2000) argue that regardless of formal titles, each member of a campus community (faculty, staff, administration) can serve as a leader, stating, “...students will implicitly generate their notions and conceptions of leadership from interactions inside the classroom and in the residence hall, through campus work and participation in campus activities, and through what is taught intentionally and across the educational experience" 
(p. 7). College students tend to consider leaders in terms of self-confidence, level of responsibility, care for others, and charisma (Zekan et al., 2012). It is not uncommon for college students to hold a systemic and hierarchical perspective of leadership (Vari, 2005), which has implications for the potential limitations of broad thinking of leadership. Caza and Rosch (2013) report that college-level students considered the following four qualities as critical to leadership --service to the community, open-minded thinking, holding high values, and comfort with change. While these qualities may be relevant to helping the students develop as leaders, we wondered if the students consider these leadership qualities when seeking support from campus personnel.

Students' constrained views of leadership may seek support from campus leaders they admire based on the leaders' characteristics (Mecham, 2012). Yet, perceptions of leadership based on the leader's characteristics reflect the potential for the lack of awareness of the many other factors associated with leader effectiveness and leadership placement, particularly on a college campus (Van Der Bijl, 2017). The constrained view of leadership may have implications about how students approach situations on a college campus in which they need support and leadership to resolve. Thus, delving deeper into college students' perceptions of leadership is critical to understanding who students may perceive as the leaders and why, who they approach for support and why, and the alignment of student expectations with common campus leadership structures.

\subsection{College Students Perceptions and Interactions of Campus Leadership}

According to Douglas MacArthur cited in Muteswa (2016), "A true leader has the confidence to stand alone, the courage to make tough decisions, and the compassion to listen to the needs of others" (p. 135), which is how many leaders of college campuses are defined. Unfortunately, leaders on college campuses can be intimidating to those they are leading (Kramer, 2006). According to Chindia and Kibera (2015), many followers are unwilling to seek support from someone they view as intimidating. This outcome can be extremely unfortunate to all personnel affiliated with a college campus. The negative stereotypes given to leaders can cause students who are intimidated by campus leaders to disengage and avoid campus leaders. As we are all aware, college administrators, faculty, and staff work diligently to advocate for the success of all students by providing good leadership qualities such as being inspirational, humble, committed, and can effectively communicate (Muteswa, 2016). However, in our search of the literature, we could not locate any empirical studies of college student perceptions of and interactions with campus leaders, particularly focusing on positive interactions. Therefore, our research is an attempt to fill this gap in the literature.

Another potential reason for the lack of student interaction with campus leaders may be a lack of awareness or separation from the leaders. Part of the separation may be explained by the social structure of leaders and followers, in which leaders are identified as a group and not recognized as individuals (Cluley, 2008). The social separation may be a barrier for students considering campus leaders as part of their social structure and therefore do not consider seeking or identifying the leaders. It may also be possible that students do not perceive that campus leaders can provide added value to their college experience because they are so consumed with additional responsibilities. As Maccoby (2004) argues, followers need to perceive benefit from their leaders, and if they do not think their leaders will help them achieve their goals, the followers will not follow. Thus, it is possible that if students do not perceive a campus leader can help them solve an issue or grow, then they will not seek to connect with the leader. Students tend to avoid "bothering" campus leaders with their problems, which provided us with justification for exploring students' perceptions and practices for engaging with campus leaders.

\subsection{Students in Distress}

In recent years, researchers have extensively explored best practices for leading students through times of crisis on college campuses (Gigliotti 2019; Holzweiss et al., 2020; Zdziarski, 2006;); however, the relationship dynamic between leaders and distressed students remains largely overlooked.

According to American College Health Association (2019), 87.4\% of students surveyed reported feeling overwhelmed by all they had to do within the last 12 months, and 55.9\% reported feeling helpless. Additionally, $65.7 \%$ of respondents shared feelings of overwhelming anxiety, with $45.1 \%$ feeling so depressed it was difficult to function. Of further concern, $56.1 \%$ of those surveyed reported at least one of fifteen major life events as traumatic or very difficult to handle.

Owen and Rodolfa (2009) sought to identify who students reach out to when experiencing psychological stress and found that due to their frequent interactions, faculty and staff members are often the first to recognize students in distress, not university counseling centers. The authors recommend creating a "campus community of care" to help meet the increased demand for support services during students' time of distress. Further research is necessary to support campus leaders' understanding so that they are better positioned to address the complex 
needs of students during times of adversity.

\subsection{College Students Support Structures}

College is full of many experiences that students do not anticipate, and, therefore, students are likely to need support to navigate the situations. However, if students are not aware of the campus leaders who have the skills and knowledge to help them navigate the circumstances, the students may be unable to take advantage of critical support structures effectively. According to Spady (1970), students who withdrew from college did so because they lacked a social support structure. Demaray (2005) conceptualizes 'social support' as "transpiring from multiple sources (parents, teachers, close friends, classmates, and school) and consisting of multiple types (emotional, informational, appraisal, and instrumental), which may serve to improve a student's adjustment and outcomes (p. 691)." Social support through campus leadership is a vital aspect of student confidence development, campus connection, and overall success.

Confidence and support can be created and promoted for students by those they share experiences with and through relationships (Barnes, 2010). The experiences and relationships should be guided by and developed with campus leaders. Those that students develop relationships with can encourage the students (Astin, 1993; Tinto, 1987), contributing to student retention and success. The support a student has with the campus leadership determines the level of a students' commitment to the institution (Aljohani, 2016), which influences students' decisions to remain at an institution (Spady, 1971). Initiatives to foster the essential commitment by students to an institution are typically led by campus leadership and require student participation. The levels of support from campus leaders and the students' motivation are likely to be predictive of the academic and social compatibility between the student and institution. The connection or adaptation of and for the student is essential in achieving the overall goal of student success.

Students who socially integrate or develop a connection to the campus increase their commitment to the institution and are more likely to graduate (Tinto, 1975). The contact between students and college support structures is so critical that the quantity and quality of the interactions are predictive of students' college persistence (Tinto, 1990). There are several avenues for students and campus leaders to develop a connection; however, electronic communication has allowed for a fast and personalized way to interact. Efficient communication enables campus leaders to create deeper relationships with the student body (Demetriou \& Schmitz-Sciborski, 2011). Today, campus leadership can remain connected even if they were not physically present.

In addition, college support systems must assist the students in creating a sense of belonging. The development of a sense of belonging must be a collaborative effort led by campus leadership. The support must begin with the recruitment of the student and continue through graduation (Hossler, 1984). According to Demetriou and Schmitz-Sciborski (2011), all higher education institutions should provide easily accessible academic, personal, and social support services. Overall, the leaders of college campus support systems and student success initiatives must develop a relationship with the diverse student population to understand and accommodate students' needs and wants. Thus, there is justification for further exploring the college students' perceptions of and engagement with campus leaders and administrators.

\section{Methodology}

We used a cross-sectional methodology and survey research to gather the quantitative and qualitative data needed to answer our overarching research question: What are college students' knowledge, perceptions, and interactions with campus leaders? To help frame our research, we generated the following guiding research questions:

- Who do college students identify as the leaders on campus, and why do they perceive them as leaders?

- Who do college students go to for help solving campus-related problems? And why do they go to these people?

- How do college students describe the leadership of those who they identify as the leaders they rely on for support?

- What are students' general perceptions of leaders and campus leadership?

- Why do college students avoid interactions with campus leaders?

\subsection{Participants}

The participants for our research study were undergraduate students recruited from three different college campuses. We invited 5,870 students to participate, and we had 130 students follow the link in our invitation to 
our survey, and 60 students complete our survey. The participants were on average 23.43 years old $(S D=8.09)$. We had 49 participants identify as female and 11 identify as male. Over three-quarters of the participants (78\%) identified themselves as Caucasian, $8 \%$ identified as Black, 5\% as Native American, $3 \%$ as Hispanic, 3\% as Asian, and 3\% identified as Other. Most students $(88 \%)$ were attending school using financial aid, two thirds (66.7\%) indicated that more than $50 \%$ of their classes were online, two thirds (66.7\%) indicated that they worked outside the home, two thirds (66.7\%) indicated that neither parent had a bachelor's degree. Almost three-quarters of the participants (73.3\%) indicated that they lived off-campus. Four-fifths $(80 \%)$ indicated that they did not hold a leadership role on campus, and the same percentage of students indicated that they had reliable internet access.

\subsection{Survey Design}

Given the unique focus of our research and lack of literature related to the topic, we determined it was necessary to develop a survey to gather the data needed to answer our research question. We combined our knowledge of leadership and work with undergraduate students to create a cache of survey items designed to assess students' perspectives of leadership on college campuses aligned with the potential experiences and thoughts of undergraduate students.

We started our survey development by brainstorming and creating a cache of related selected and open-response item prompts. We followed this session with the independent creation of approximately five selected-response items for each of our focus areas and several free-response items. Following our independent work, we pooled our items to form a collective pool of potential survey items. We then met and reviewed the items starting with identifying the alignment of the items with our four guiding research questions focused on perceptions and interactions with leadership, and then how appropriate the items were for undergraduate students' perspectives and experiences. As we focused our items for our final survey, we were also attentive to the survey's length.

Through our review process, we narrowed our items down to 22 selected-response items and four free-response prompts. The number of items per subscale ranged from five to seven. To establish the validity of the items for measuring students' perceptions of leadership, particularly on college campuses, we shared our instrument with four faculty members who research student services and campus leadership. Based on their comments, we made slight modifications to a few of our items to clarify and contextualize for students. Our final instrument included a combination of 25 positive and negatively stated selected-response stems such as, "Campus leaders are unapproachable" and "I perceive campus leaders as role models" which the students responded to on a five-point Likert scale with " 1 " representing "strongly agree" to " 5 " representing "strongly disagree." Our four free-response prompts included statements such as. "Why would you avoid contacting a campus leader?" Our reliability test of the 25 items revealed a Cronbach's alpha of .90 , indicating an acceptable level of internal consistency.

\subsection{Data Collection}

Our data collection and communication transpired virtually. Our population consisted of students who were enrolled in the first-year student success courses in fall 2019. The students who participated in our research were from three state institutions. Two of the institutions were state universities of similar size, and the third institution was a public community college. We emailed a request to complete our survey to students enrolled in the college student success courses at the three institutions. We sent emails to 1,195 students at institution A, 800 students at institution B, and 3,762 at institution C. Institution A had 35 students participate, institution B had 26 students participate, and institution $\mathrm{C}$ had 96 students participate. We collected data for two weeks in the fall of 2020.

\subsection{Data Analysis}

\subsubsection{Quantitative Data}

We began our analysis by examining the dataset to ensure we only retained the responses for those participants who answered at least $90 \%$ of the selected response items. Following the initial screening, we examined the dataset to see if we could detect a trend in the missed items, which we failed to do, suggesting the missed items were random and not likely purposeful. Therefore, we replaced the missed selected response answers with the series mean, using the option in the statistical analysis software. We then re-coded the responses to the negatively stated items and calculated the average score of the summed items for each of our four subscales. In Table 1, we include the means, standard deviations, and correlations for our four subscales. Following the subscale calculations, we re-coded the item responses to the original value for analysis and reporting. 
Table 1. Mean, Standard Deviations, and Correlations of the Four Subscales $(\mathrm{N}=60)$

\begin{tabular}{lllcll}
\hline & M (SD) & $\begin{array}{l}\text { Who are } \\
\text { the leaders }\end{array}$ & $\begin{array}{c}\text { Perceive campus } \\
\text { leadership }\end{array}$ & $\begin{array}{l}\text { Go to } \\
\text { for help }\end{array}$ & $\begin{array}{l}\text { Why } \\
\text { avoid }\end{array}$ \\
\hline Who are the leaders & $2.62(.46)$ & - & $.617^{* *}$ & $.393^{* *}$ & $.584^{* *}$ \\
Perceive campus leadership & $2.82(.70)$ & & & $.696^{* *}$ & $.614^{* *}$ \\
Go to for help & $2.55(.94)$ & & & $.477^{* *}$ \\
Why avoid & $2.76(.70)$ & & & - \\
\hline$* * 01$ & & & & &
\end{tabular}

\subsubsection{Qualitative Data}

We analyzed the qualitative data after creating a set of a priori codes aligned with our survey prompts. We developed the a priori codes based on research that had been conducted on leadership characteristics. However, there was minimum literature available regarding students' perceptions of leadership. Thus, as we analyzed the data, it became apparent there was a need for additional codes aligned with the participants' input. We then applied the emergent and a priori codes in our analysis to ensure we accurately represented the data.

\section{Results}

\subsection{Who Do They Identify as Leaders}

Our first guiding research question asked, who do college students identify as the leaders on campus, and why do they perceive them as leaders? We continued our analysis by examining the outcome of the coding of our free response item asking the students, who do you identify as the leaders on campus, and why do you perceive them as leaders? In Table 2, we have included our codes, the frequency of related responses, and representative responses from our participants. We found most students felt that advisors were who they identified as leaders on campus. In addition, participants also identified faculty members, administrators, and/or parent/family members as leaders. Students also noted they do not have someone they view as a leader on campus. Additional identified leaders on campus were friend/peer, high school advisor, coach, and myself.

Table 2. Codes, Frequency, and Representative Responses to Who is a Leader on Campus

\begin{tabular}{|c|c|c|}
\hline Code & $\mathbf{N}$ & Representative Response(s) \\
\hline Advisor & 26 & My advisor, for obvious reasons. \\
\hline Faculty Member & 8 & $\begin{array}{l}\text { My professors in that class or my advisor. I go to them because if I have a } \\
\text { problem, they usually do their best to help me out. }\end{array}$ \\
\hline Friend/Peer & 3 & $\begin{array}{l}\text { A friend in the field. He completed his graduate program at the same institution, } \\
\text { and he is more available to me than others in the department on campus. }\end{array}$ \\
\hline Administrator & 5 & $\begin{array}{l}\text { The instructor is a staff member that I seek guidance in regarding personal } \\
\text { issues, life questions, and random things we find ourselves talking about. For } \\
\text { higher education, she does push me to be a great student and wished me the best } \\
\text { in my academic career. }\end{array}$ \\
\hline Parent/Family Member & 5 & My sister. She has a doctorate degree, she has been through higher education. \\
\hline High School Advisor & 1 & Family or high school advisor. \\
\hline Does Not Have One & 4 & I don't know who I would go to. \\
\hline Coach & 2 & My coach because she can always get me the help I need. \\
\hline Myself & 1 & $\begin{array}{l}\text { Myself. Due to being misdirected from college personal repeatedly. I honestly } \\
\text { do not trust anyone to give me advice on anything. I have a history of trusted } \\
\text { advisors and it has not worked in my favor. }\end{array}$ \\
\hline
\end{tabular}

\subsection{Who do They go to for Help}

Our second guiding research question asked, who do college students go to for help solving campus-related problems? And why do they go to these people? To answer this question, we began by analyzing the students' responses to our selected-response items aligned with who they go to for help (see Table 3). We found participants agreed that there is a campus employee they can count on for help when in need, they feel supported by people who work at the institution, and they have someone who works on campus that cares about them. Students were neutral towards feeling that they have built a support network that includes campus employees. Lastly, students disagreed with not having anybody on campus they can go to for help in pursuit of higher 
education.

Table 3. Means, Standard Deviations, and Medians for Who do College Students go to for Help

\begin{tabular}{lll}
\hline Item & M (SD) & Med \\
\hline There is a campus employee I can count on for help when I am in need. & $2.32(1.16)$ & 2.00 \\
I feel supported by people who work at the institution. & $2.32(1.07)$ & 2.00 \\
Someone who works on campus cares about me. & $2.42(1.11)$ & 2.00 \\
I have built a support network that includes campus employees. & $3.33(1.08)$ & 3.00 \\
I don't know anybody on campus I can go to for help in my pursuit of higher education. & $3.62(1.18)$ & 4.00 \\
\hline
\end{tabular}

We continued to answer this question by analyzing the responses and frequency of the codes to the prompt; Who do you seek assistance from when you experience problems related to your pursuit of higher education, and why do you go to this person? In Table 4, we have included our codes, the frequency of related responses, and representative responses from our participants. We found most students seek assistance from those they feel get things done, are knowledgeable, and exhibit a sense of understanding and/or empathy. Participants also seek help when experiencing problems from those they have established a connection with due to a shared experience and/or relationship. In addition, providing comfort and motivating were attributes noted as reasons for students to seek assistance from someone they identified as a leader.

Table 4. Codes, Frequency, and Representative Responses for Why They go to the Identified People for Help

\begin{tabular}{|c|c|c|}
\hline Code & $\mathbf{N}$ & epresentative Response(s) \\
\hline Knowledge & 8 & $\begin{array}{l}\text { My academic advisor or my friend. Academic advisor knows more about the higher } \\
\text { education, friend knows more about me and what I am capable of doing and not doing. }\end{array}$ \\
\hline Connections & 4 & $\begin{array}{l}\text { I go to an employee of the institution because I have known her since high school, and she } \\
\text { is always open to listen and guides me in the right direction. }\end{array}$ \\
\hline Comfort & 2 & $\begin{array}{l}\text { Individuals who are employed at the institution. They make me feel valued and that my } \\
\text { troubles and concerns mean something. They do an amazing job. }\end{array}$ \\
\hline Shar & 4 & My older siblings. Because I have 8 of them and they have all been to college. Campus \\
\hline Expe & & $\begin{array}{l}\text { response has to be by email so I would rather talk to someone face to face. It helps me think } \\
\text { and remember better. }\end{array}$ \\
\hline $\begin{array}{l}\text { Und } \\
\text { Emp }\end{array}$ & 7 & $\begin{array}{l}\text { I go to a professor who is a part of the education department because she is very } \\
\text { experienced and is very willing to help me in whatever I need whether that be advice, or } \\
\text { advisement in my classes, etc. She knows what she is doing and if she cannot answer a } \\
\text { question that I have, she is willing to help me. }\end{array}$ \\
\hline Relat & 4 & $\begin{array}{l}\text { I generally reach out to my academic advisor because they are the only person who has } \\
\text { bothered to respond to me. }\end{array}$ \\
\hline $\begin{array}{l}\text { Gets Things } \\
\text { Done/Reliable }\end{array}$ & 9 & $\begin{array}{l}\text { My advisor because she presents herself as being helpful and my sister because she is a } \\
\text { couple of years ahead of me in school. }\end{array}$ \\
\hline Motivating & 1 & $\begin{array}{l}\text { A staff member that I seek guidance in regarding personal issues, life questions, and } \\
\text { random things we find ourselves talking about. For higher education, she does push me to } \\
\text { be a great student and wished me the best in my academic career. }\end{array}$ \\
\hline
\end{tabular}

\subsection{Perceptions of the Leadership of those Who Students Rely on for Support}

Our third guiding research question asked, how do college students perceive and describe campus leadership? To answer this question, we began by analyzing the students' responses to our selected-response items aligned with how college students describe the leadership of those they identified as leaders they rely on for support (see Table 5). We found that students agree the campus leaders are friendly to students. The participants were neutral toward the campus leaders creating a welcoming environment for students, the leadership on campus is helpful to me, the perception of the campus leaders as role models, and all employees of the college are leaders. We found the participants were between neutral and agree with the campus leaders being unapproachable. Lastly, students disagreed that only the college administrators are leaders. 
Table 5. Means, Standard Deviations, and Medians for How Students Describe Leaders

\begin{tabular}{lll}
\hline Item & M (SD) & Med \\
\hline Campus leaders are friendly to students. & $2.33(.91)$ & 2.00 \\
The campus leaders have created a welcoming environment for students. & $2.55(.93)$ & 3.00 \\
The leadership on campus is helpful to me. & $2.80(1.05)$ & 3.00 \\
I perceive the campus leaders as role models. & $2.82(1.00)$ & 3.00 \\
All employees of the college are leaders. & $2.93(1.25)$ & 3.00 \\
Campus leaders are unapproachable. & $3.42(1.03)$ & 3.50 \\
Only the college administrators are leaders. & $3.72(.94)$ & 4.00 \\
\hline
\end{tabular}

We continued to answer our third guiding research question by analyzing the responses and frequency of the codes for the free-response prompt; how do college students describe the leadership of those who they identify as the leaders they rely on for support? In Table 6, we have included our codes, the frequency of related responses, and representative responses from our participants. We found that most students described the leadership of those they identified as leaders by their role/position. However, students also noted they viewed individuals who were willing and able to make progress or get things done, and those who were helpful as leaders. Additional attributes used to describe leadership were those who were visible and inspirational.

Table 6. Codes, Frequency, and Representative Responses for How They Describe Leadership

\begin{tabular}{|c|c|c|}
\hline Code & $\mathbf{N}$ & Representative Response(s) \\
\hline Role/Position & 9 & President vice president. College degrees in education administration. \\
\hline Visibility & 2 & $\begin{array}{l}\text { I think the President, faculty, and other Student Life organization personnel are the campus } \\
\text { leaders because they work hard to make the campus a better place and connect with the } \\
\text { students. }\end{array}$ \\
\hline Get Things & 6 & I think the campus leaders are driven young adults who have worked their way up to a \\
\hline Done/Reliability & & $\begin{array}{l}\text { leadership role. On the other hand, I know many campus leaders who were simply elected } \\
\text { because of name recognition (popularity). }\end{array}$ \\
\hline Inspirational & 2 & $\begin{array}{l}\text { I think campus leaders are everywhere. Not just presidents of clubs, schools, and } \\
\text { organizations are leaders because they take on the said role. I believe many regular } \\
\text { students are leaders in everyday situations. They are leaders because they inspire others to } \\
\text { be great. }\end{array}$ \\
\hline Helpfulness & 6 & $\begin{array}{l}\text { In my position, I would see the RAs, RDs, professors, and higher staff are considered } \\
\text { leaders since they usually guide and assist students through problems that they would } \\
\text { have, and students learn from them. Plus, with my experience as an RA myself, I feel } \\
\text { responsible for my residents somewhat. }\end{array}$ \\
\hline
\end{tabular}

\subsection{Important Qualities of a Campus Leader}

Our fourth guiding research question asked, what are students' general perceptions of leaders and campus leadership? To answer this question, we began by analyzing the students' responses to our selected-response items aligned with their perceptions of effective leaders (see Table 7). We found the participants tended to agree that the goal of a leader is to inspire others, and that students can be leaders of their college. The participants were neutral toward having met with campus leaders, leaders needing formal training, and effective/great leaders tell people what to do.

Table 7. Means, Standard Deviations, and Medians for Qualities of Effective Leaders

\begin{tabular}{lll}
\hline Item & M (SD) & Med \\
\hline The goal of a leader is to inspire others. & $1.78(.72)$ & 2.00 \\
Students can be leaders of their college. & $1.92(.81)$ & 2.00 \\
I have met the campus leaders. & $3.05(1.19)$ & 3.00 \\
Leaders need to have formal training. & $3.10(1.18)$ & 3.00 \\
Effective/great leaders tell people what to do. & $3.25(.91)$ & 3.00 \\
\hline
\end{tabular}

To answer this question, we analyzed the students' responses to our free-response prompt, "What are the 2 most important qualities of a campus leader?" As we began our coding process, it became apparent that the participants had a more comprehensive array of qualities than we anticipated, with many qualities shared by a 
single participant. Thus, to effectively display all the participants' responses according to the frequency, we generated Figure 1. We found the students perceived the most important qualities of a campus leader were being approachable, helpful, and knowledgeable. At a more moderate frequency, the students indicated that being understanding, patient, and compassionate were important campus leader qualities. The students' responses focused almost exclusively on personality traits or relationship skills except for being knowledgeable.

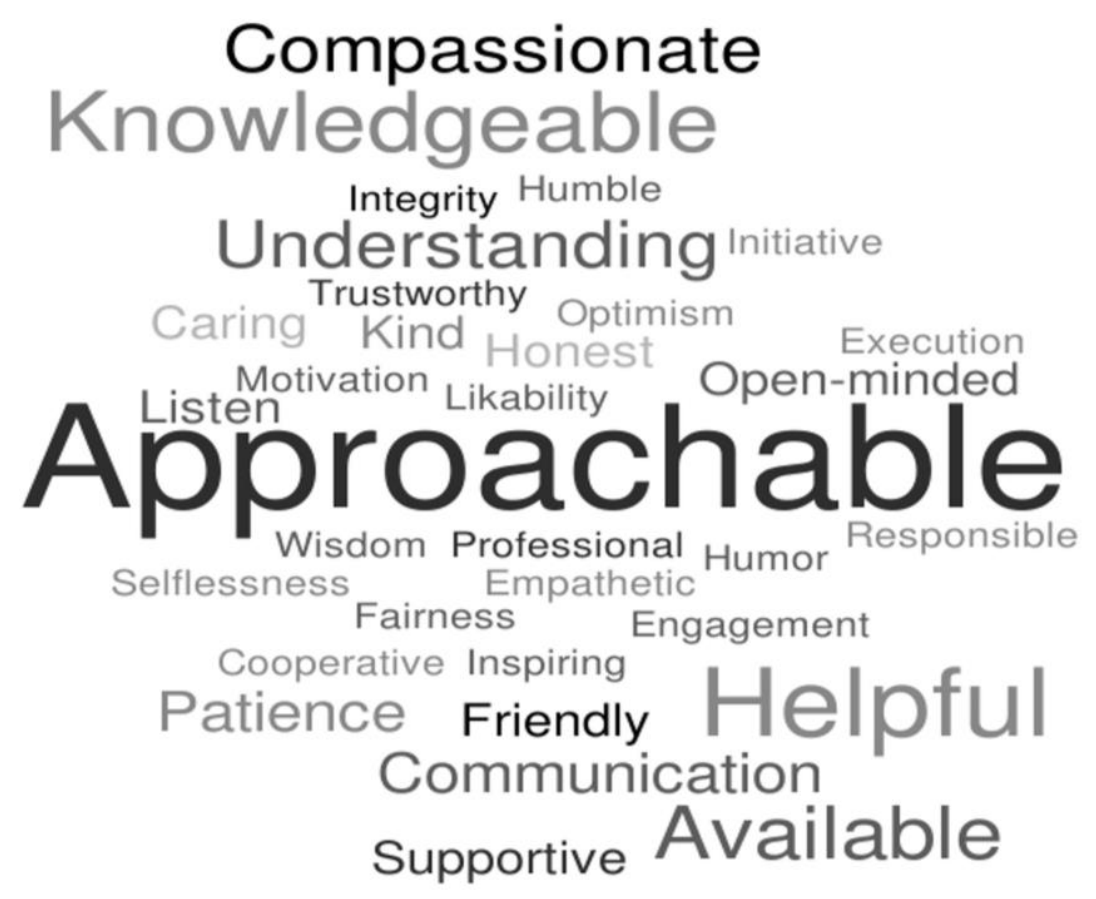

Figure 1. Important Qualities of a Campus Leader

\subsection{Why Student Avoid Campus Leaders}

Our fifth guiding research question asked, why do college students avoid interactions with campus leaders? To answer this question, we began by analyzing the students' responses to our selected response items aligned with why you would avoid contacting a campus leader (see Table 8). We found students were neutral towards feeling their problems are not important enough to bother campus leadership for help, interacting with campus leadership making them nervous, not thinking campus leaders can relate to their situation, and feeling as if campus leaders do not want to talk to them. The participants disagreed with thinking that campus leaders will judge them negatively.

Table 8. Means, Standard Deviations, and Medians for Why Avoid Campus Leaders

\begin{tabular}{lll}
\hline Item & M (SD) & Med \\
\hline My problems are not important enough to bother campus leadership for help. & $3.00(0.97)$ & 3.00 \\
Interacting with campus leadership makes me nervous. & $3.08(1.15)$ & 3.00 \\
I don't think that campus leaders can relate to my situation. & $3.25(.86)$ & 3.00 \\
I don't think campus leaders want to talk to me. & $3.30(1.01)$ & 3.00 \\
I think campus leaders will judge me negatively. & $3.55(1.02)$ & 4.00 \\
\hline
\end{tabular}

We continued to answer this question by analyzing the responses and frequency of the codes for the free-response prompt; why do college students avoid interactions with campus leaders? In Table 9, we have included our codes, the frequency of related responses, and representative responses from our participants. We found that most participants avoided campus leaders in fear of judgment, intimidation, and/or feelings of anxiety. College students also avoided campus leaders because they felt they are too busy, they do not want to bother them, they do not know who they are, and/or how to contact them. Additional codes for why campus leaders are avoided by students included they don't understand me, don't want to sound stupid, previous bad experiences, rude/condescending, do not have information/not helpful, wouldn't care, and fear of not maintaining confidentiality. 
Table 9. Codes, Frequency, and Representative Responses for Why Avoid Campus Leaders

\begin{tabular}{|c|c|c|}
\hline Code & $\mathbf{N}$ & Representative Response(s) \\
\hline $\begin{array}{l}\text { Fear of judgment/ } \\
\text { Intimidation/ } \\
\text { Anxiety }\end{array}$ & 13 & The only reason I would avoid this is because of intimidation. \\
\hline $\begin{array}{l}\text { Too busy/Don't want to } \\
\text { bother them }\end{array}$ & 11 & $\begin{array}{l}\text { It is too much work to have to coordinate with their schedule outside of my life } \\
\text { from the university. }\end{array}$ \\
\hline $\begin{array}{l}\text { Do not know who they } \\
\text { are/Do not know how to } \\
\text { contact them }\end{array}$ & 8 & Not sure where they are at. \\
\hline $\begin{array}{l}\text { Do not have } \\
\text { information/Not helpful }\end{array}$ & 5 & They're not helpful. \\
\hline Don't understand me & 4 & Sometimes I feel like my problems aren't relevant to them. \\
\hline $\begin{array}{l}\text { Don't want to sound } \\
\text { stupid }\end{array}$ & 2 & $\begin{array}{l}\text { I would avoid them not to bother them because they are busy people and } \\
\text { sometimes when I go to them because I'm struggling in a class or something I'm } \\
\text { worried they'll think I'm dumb because I am a part of the Honors program and I } \\
\text { normally keep good grades. }\end{array}$ \\
\hline $\begin{array}{l}\text { Rude/ } \\
\text { Condescending }\end{array}$ & 2 & $\begin{array}{l}\text { They're rude and condescending, they often don't have time to actually give } \\
\text { you information. Even if they do try to answer your questions, they often don't } \\
\text { actually seem to have a clue about what's going on or what they're doing. } \\
\text { They're just overall extremely unhelpful and waste of time to talk to. }\end{array}$ \\
\hline Bad previous experiences & 1 & $\begin{array}{l}\text { d rather just not approach the situation anymore. I've had a couple fall } \\
\text { fore and now I choose not to deal with that person anymore. }\end{array}$ \\
\hline They wouldn't care & 1 & I honestly do not think that they would care whoever they are. \\
\hline $\begin{array}{l}\text { Fear of not maintaining } \\
\text { confidentiality }\end{array}$ & 1 & $\begin{array}{l}\text { Fear of them telling someone my business that I told them in confidence. } \\
\text { Example other students instead of another leader that would be better to help } \\
\text { me. }\end{array}$ \\
\hline
\end{tabular}

\section{Discussion of Results}

Our research goal was to document college students' perceptions of campus administrators and other campus leaders to fill a gap in the literature. When students experience distress or challenging situations on campus, they are frequently in need of a leader to help them develop potential solutions and navigate the challenge. Thus, college student awareness and knowledge of campus leaders may be fundamental to their academic success and retention. We also argue that students benefit from understanding the roles and responsibilities of campus administrators and other campus leaders, which is critical to developing an accurate image of higher education institutions' complex and unique structure.

\subsection{Students Identification of Campus Leaders}

In our exploration of how students identify campus leaders, we found they tended to recognize members of the institution with whom they had frequent, direct contact. Our results suggest that students perceive campus leaders as those individuals who can support the students as they navigate their campus experiences. Furthermore, we found that the students' perceptions of leadership did not correlate to their respective institutions' organizational chart. Survey responses indicated students' perceptions were not swayed by traditional, positional leadership roles, which suggests the students' potentially perceived personal relevance in campus administrative structures. We also found that students conveyed a lack of understanding of the differences between higher education leadership and K-12 leadership. Multiple students' shared perceptions of university presidents and high school principals being similar roles. Similarly, the students tended to view school counselors and academic advisors in similar roles. While there may arguably be some overlap in the roles, the distinctions are much more significant, which again indicates students' lack of understanding of leadership in post-secondary education.

There are multiple implications for our findings. First, there is the need in higher education institutions to be strategic with determining who is working in positions that are frequently the first line of contact for students. Often, the first-person students contact on campus to help solve a problem or guide them toward support is by default recognized as a leader. Thus, our data suggest that students tend to associate leadership with those they trust and help them solve problems. Second, campus leaders may need to be innovative and strategic in finding 
alternative ways to create meaningful connections with students. Leaders should not assume students understand the organizational hierarchy or social norms in complex organizations. Moreover, it is likely unrealistic that it will be effective to teach students to navigate the complex organization of an institution of higher education when they are experiencing heightened stress. Third, there is a need to teach college students about the roles of college staff and administrators. The probability that students project their K-12 experiences with leadership to college leadership may result in frustration, disappointment, or embarrassment. If college students have an accurate understanding of the roles and responsibilities of campus leadership, they are more likely to interact with the leaders with aligned expectations.

\subsection{Who Students Go to for Help}

In our exploration of who students seek assistance from during times of need, we found students heavily relied on individuals they felt could be trusted, who they had a relationship with, and could provide the support necessary to solve their problems, were empathetic, provided comfort, and understanding. We posit that students perceived their problems would not be understood or substantial enough to warrant the support or assistance of a campus administrator. Further, the students also seemed to approach those they already had established relationships with and indicated they trusted the individual. We also found evidence to suggest that if the students receive support from a trusted campus personnel, they may seek support from that person on a range of issues, regardless of the alignment to the campus personnel's role and responsibility.

The implications for our finding include the need to assure students understand the roles and responsibilities of campus personnel and leaders. It is possible that students could overwhelm certain campus personnel if they continually rely on these individuals to support them. As we shared previously, many students may transfer their knowledge of leadership and personnel roles from their K-12 education to their post-secondary experiences, a process that may lead them to experience frustration and disappointment. A potentially ideal location for such a discussion is in first-year student success or students in transition courses. Exploring how student awareness of campus leadership structures and personnel roles and responsibilities influences their perceptions of campus leadership is an excellent direction for future research.

\subsection{How do They Describe Identified Leaders}

Our analysis revealed a strong focus by the students on the leaders they go to for support as being helpful, getting things done, being reliable, and being visible. However, they also recognized campus leaders in general by the role or position they held on campus, such as campus president. We posit that students primarily consider some people as campus leaders (e.g., academic advisors) because they can provide them with support and engage in the problem-solving needed to get something done. In addition, they are potentially approaching these leaders in times of vulnerability and distress and, therefore, need a compassionate, caring leader to help them negotiate their issues. Again, we maintain they are not likely a student is going to approach a campus leader they have no relationship with when they are experiencing stress.

One implication for our findings is the potential need to assure the campus personnel that students rely on for support and recognize as leaders are provided with sufficient professional development to ensure they are prepared to meet the needs of the students. Another implication is the potential need to reduce the engagement of some campus personnel with helping students solve issues that are not aligned with their position, role, or responsibilities. Thus, there is a need to guide students to the appropriate resources to ensure students get the support they need from the most appropriate personnel. Researching how students react when redirected to gain support for solving their problems would be an interesting direction for future research.

\subsection{Important Qualities of Campus Leaders}

We found our participants had overlapping perceptions of the positive qualities of leaders with the findings of Zekan and colleagues (2012). We also found some overlap between the students' perceptions of campus leaders' positive qualities and those they go to for help on campus. Yet, we also found that the students were not aware of the responsibilities of campus leaders and the roles they fulfill. Thus, we speculate that the students were projecting their perceived desired qualities of campus leaders based on their expectations rather than their knowledge of campus leadership. Again, they may be relying on their knowledge of leadership models from their K-12 school experiences as they considered the expectations for the qualities of an effective campus leader.

One implication for our finding is the need for campus leaders to be aware of students' knowledge and expectations of them as leaders. The potential misalignment between student expectations and perceptions and the actual situation for campus leaders could again lead to disappointment and frustration. There may be a high benefit to campus leaders in assuring students have at least some levels of working knowledge of the roles, 
responsibilities, and structure for campus leadership. A potential fruitful direction for research may be an exploration and comparison of what campus leaders and students consider to be essential leadership qualities.

\subsection{Avoiding Interactions with Leaders}

We found that students tend to avoid campus leaders due to perceptions that they will not understand the students' problems, care about the issues, or potentially make the student feel ashamed or judged. We speculate that the students may be projecting their potential emotions onto the leaders based on their prior experiences, again perhaps from the K-12 education, other interactions with leadership, including in their post-secondary education. We also posit that the students may have held negative images of interactions with leadership from other sources (e.g., popular media, experiences shared by others) which led them to form opinions about potential interactions with campus leaders. The implications for the potential for students to avoid interacting with campus leaders is the lack of connecting with the campus and learning more about how universities work. Another implication is the potential isolation of campus leaders from students, leading to a disconnect between the work of the leaders and the students' experience. A needed line of research is a more in-depth exploration on why students may avoid campus leaders.

\section{Study Limitations}

The first limitation of our study is the lack of an ability to determine why the students responded as they did because our data collection was anonymous. Thus, we could not follow up with students to ask them to clarify or provide more information. However, there was consistency in our data which suggests that the students answered in ways that reflect a shared experience. Exploring in-depth students' perceptions of campus leadership and their interactions with the leaders is a needed direction for future research.

The second limitation of our research was the limited sample size of our sample size and the potential bias associated with those who participated. Even though our number of participants was constrained, we did find consistency in our responses, which indicates our sample was likely representative of a large portion of the student bodies of the institutions. Replicating our research with a larger student population ratio may be needed to confirm our exploratory study.

The third limitation of our study was the potential that students responded to our survey using a social desirability bias. Thus, it is possible the answers the students provided were not accurate representations of their actual perceptions and experiences. Future research may need to focus on focus groups and personal interviews to delve deeper into the perceptions and practices of students to determine if their responses on our survey are consistent with the dialog about campus leadership. It is important to note that the students' answers were consistent with students' perceptions and practices with whom we have had informal conversations.

The fourth limitation of our research is our data collection took place in a region in the south-central United States at three public institutions. It may be possible that students at different classifications of institutions or institutions located in other areas, regions, or countries may respond differently. Thus, a fruitful direction for future research is to gather similar data at various institutions and in other geographic locations and examine the data for similarities and differences with the results of our study.

\section{Conclusion}

Our research goal was to address the gap in the literature by exploring college students' knowledge, perceptions, and identification of campus administrators, faculty members, and staff as leaders, and their interactions with these leaders. We discovered issues with students having a proper understanding of campus leadership and who the leaders on campus are and students avoiding campus administration in fear of judgment, intimidation, and/or feelings of anxiety. While the levels of hierarchy can be challenging to understand and ever-evolving, the leaders of higher education institutions must support student knowledge of campus leaders, the leaders' roles and responsibilities, and how developing relationships with campus leaders can be beneficial to their holistic success. We hope others find our research of value to inform additional investigation lines and support evidence-based practice.

\section{References}

Aljohani, O. (2016). A comprehensive review of the major studies and theoretical models of student retention in higher education. Higher Education Studies, 6(2), 1-18. https://doi.org/10.5539/hes.v6n2p1

American College Health Association. (2019). American College Health Association - national college health assessment II: Spring 2019 reference group executive summary.

Astin, A. W. (1993). What matters in college? Four critical years revisited. Jossey-Bass. 
Astin, A. W., \& Astin, H. S. (2000). Leadership reconsidered: Engaging higher education in social change. W. K. Kellogg Foundation.

Barnes, B. J. (2010). The nature of exemplary doctoral advisors' expectations and the ways they may influence doctoral persistence. Journal of College Student Retention: Research, Theory \& Practice, 11(3), 323-343. https://doi.org/10.2190/CS.11.3.b

Bolman, L. G., \& Gallos, J. V. (2010). Reframing academic leadership. Jossey-Bass.

Caza, A., \& Rosch, D. M. (2014). An exploratory examination of students' pre-existing beliefs about leadership. Studies in Higher Education, 39(9), 1586-1598. https://doi.org/10.1080/03075079.2013.801434

Chindia, E. W. \& Kibera, F. N. (2015). Leadership and accuracy of performance forecasting in operations management. Prime Journal of Business Administration and Management, 5(4), 1815-1821.

Cluley, R. (2008). The psychoanalytic relationships between leaders and followers. Leadership, 4(2), 201-212. https://doi.org/10.1177/1742715008089638

Demaray, M. K., Malecki, C. K., Davidson, L. M., Hodgson, K. K., \& Rebus, P. J. (2005). The relationship between social support and student adjustment: A longitudinal analysis. Psychology in the Schools, 42(7), 691-706. https://doi.org/10.1002/pits.20120

Demetriou, C., \& Schmitz-Sciborski, A. (2011). Integration, motivation, strengths, and optimism: Retention theories past, present and future. In Proceedings of the 7th National Symposium on student retention (Vol. 201).

Gigliotti, R. A. (2019). Crisis leadership in higher education: Theory and practice. Rutgers University Press. https://doi.org/10.2307/j.ctvscxrr0

Haber, P. (2012). Perceptions of leadership: An examination of college students' understandings of the concept of leadership. Journal of Leadership Education, 11(2), 26-51. https://doi.org/10.12806/V11/I2/RF2

Holzweiss, P. C., Walker, D. W., Chisum, R., \& Sosebee, T. (2020). Crisis planning for online students: Lessons learned from a major disruption. Online Learning, 24(2), 22-37. https://doi.org/10.24059/olj.v24i2.2135

Hossler, D. (2000). The role of financial aid in enrollment management. New Directions for Student Services, 2000(89), 77-90. https://doi.org/10.1002/ss.8906

Kramer, R. M. (2006). The great intimidators. Harvard Business Review, 84(2), 88-96.

Kuh, G. D., Kinzie, J., Schuh, J. H., \& Whitt, E. J. (2005). Never let it rest lessons about student success from high-performing colleges and universities. Change: The Magazine of Higher Learning, 37(4), 44-51. https://doi.org/10.3200/CHNG.37.4.44-51

Love, D., Trammell, A., \& Cartner, J. (2010). Transformational leadership, campus climate and it's impact on student retention. Journal of Organizational Culture, Communications \& Conflict, 14(2), 75-81

Maccoby, M. (2004). Why people follow the leader: The power of transference. Harvard Business Review, 82(9), 76-85.

Mecham, B. L. (2012). Students' perceptions of academic department leadership. Idaho State University.

Muteswa, R. (2016). Qualities of a good leader and the benefits of good leadership to an organization: A conceptual study. European Journal of Business and Management, 8(24), 135-140.

Owen, J., \& Rodolfa, E. (2009). Prevention through connection: Creating a campus climate of care. Society for College and University Planning, 37(2), 26-33.

Spady, W. G. (1970). Dropouts from higher education: An interdisciplinary review and synthesis. Interchange, 1(1), 64-85. https://doi.org/10.1007/BF02214313

Spady, W. G. (1971). Dropouts from higher education: Toward an empirical model. Interchange, 2(3), 38-62. https://doi.org/10.1007/BF02282469

Tinto, V. (1975). Dropout from higher education: A theoretical synthesis of recent research. Review of Educational Research, 45(1), 89-125. https://doi.org/10.3102/00346543045001089

Tinto, V. (1987). Leaving college: Rethinking the causes and cures of student attrition. University of Chicago Press.

Tinto, V. (1990). Principles of effective retention. Journal of the First-Year Experience \& Students in Transition, 2(1), 35-48. 
Van Der Bijl, C. (2017). An exploration of Cardiff metropolitan university students' perceptions of whether effective leadership is a trait, or if it can be taught. Doctoral dissertation, Cardiff Metropolitan University.

Vari, A. (2005). An exploration of factors associated with college students' attitudes and beliefs about leadership. Indiana University of Pennsylvania.

Zdziarski, E. L. (2006). Crisis in the context of higher education. In K. S. Harper, B. G. Paterson \& E. L. Zdziarski (Eds.), Crisis management: Responding from the heart (pp. 3-24). National Association of Student Personnel Administrators.

Zekan, S. B., Peronja, I., \& Russo, A. (2012). Linking theory with practice: Students perceptions of leaders and leadership characteristics. Procedia-Social and Behavioral Sciences, 41, 237-242. https://doi.org/10.1016/j.sbspro.2012.04.027

\section{Copyrights}

Copyright for this article is retained by the author(s), with first publication rights granted to the journal.

This is an open-access article distributed under the terms and conditions of the Creative Commons Attribution license (http://creativecommons.org/licenses/by/4.0/). 